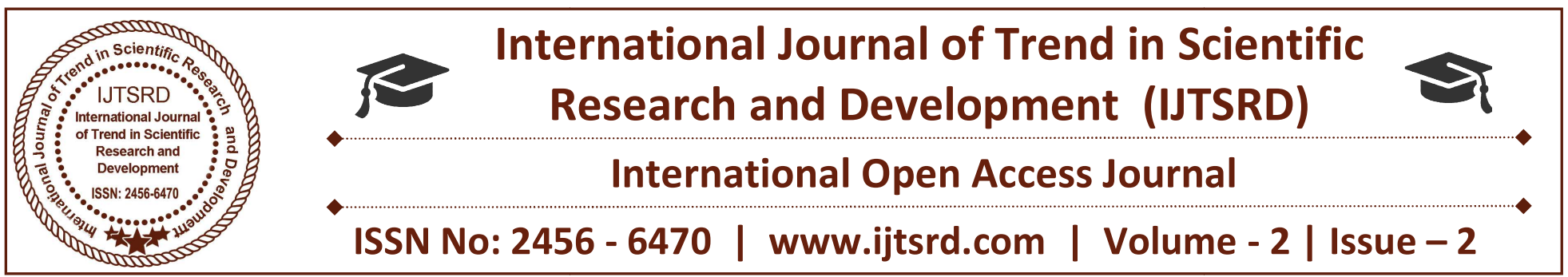

\title{
Importance of Value Chain Analysis in Interrelated Relationships
}

\author{
Arelli Ankitha \\ MBA Finance, Pragathi School of \\ Information Technology, Hanamkonda, Telangana
}

\begin{abstract}
The concept of "value chain" was introduced in the 1985 "Competitive Advantage" book by management expert Michael Porter. Porter indicated that companies would be able to optimize value when it comes to sales, outbound logistics, marketing and sales and services from production and sales transactions. Companies enjoy many critical benefits by implementing the Value Chain Management Principles with Distribution Channel Partners. The purpose of this paper is to identify the key features of business-to-business relations in the early stages of the relationship that affects the successful creation of valuable chains. The values provide a decisive tool for identifying these features to maintain the efficient development of the chain process.
\end{abstract}

Keywords: value chain, Management,business, Competitive Advantage

\section{Introduction}

The value chain concept was first used in accounting analysis a few years before Michael Porter suggested that it could be used in strategic analysis. Reiki, Jensen \& Ponte (2000) came up with French filer systems, analyzing the analysis of domestic markets and ignoring dynamic adjustments to industry features and relationships by highlighting and mapping specific physical cargoes in an industry. Total value by the company is the total amount built across the entire organization. According to the Lynch (2006) value, the value is added to an organization and connects the process with the company's core performance components.

\section{Value chain analysis}

Value Chain Analysis (VCA) identifies its primary and supporting activities that add value to its primary product and analyzes these steps to minimize or reduce these costs. Changing inputs into outputs represents an organization's internal operations.A valuable chain is a company that operates in a particular industry, representing operations that organize a valuable product or service for the market. This concept comes through business management and first described by Michael Porter in his 1985 Best Seller, Contender Advantage: Creating and Stabilizing Superior Performance.

The value of the value of the chain depends on the scenario of the company's process, the idea of making the system (or service) the system as a system, through inputs, transition processes and products through subsystems. Inputs, Transformation Processes and Outputs Buy and utilize resources - Money, Labor, Equipment, Equipment, Buildings, Land, Administration and Maintenance. How Value Chain Operations Determines Expenses And Improve Profits. The proper level of building a value chain is not a business division, division or corporate level. The products are ordered by the chain of operations, and each activity produces some value of the product. The chain of programs gives products more valuable than added value from all activities.

The diamond cutter's work cost and value chain can be distinguished. Cutting activity may have a lower cost, but most of the activity value adds to the 
product, because it is less expensive than a stiff diamond cut diamond. Typically, the auditing, which deals with the documentation, assessment and executable policies of the value chain and processes, is in the critical part of the business quality certification, e.g. ISO 9001. A company's value chain forms a part of a larger current, the porter calls a value system. A value system, or industry value chain, includes suppliers that provide the company's required inputs along with their value chains. After creating company products, these products are distributed by the value chains (including their own value chains), all the way to customers. All components of this chain are included in the system. To achieve a competitive advantage and to continue, and to support that purpose with information technologies, a company needs to understand every part of this value system.

\section{Porter's Value Chain Analysis}

The value of porter's value is its approach to the chain analysis. Porter's value focuses on chain analysis departments and programs, rather than sections of the departments and accounting expenses rather than the central category of customers. This system connects systems and operations to each other and can have any impact on costs and benefits. Consequently, it is clear (where value chain analysis) can determine the origins of the value and damages sources in the organization.

Value chain analysis is a strategy tool used to analyze internal company operations. Its goal is to identify the most valuable (ie the source of cost or differential purpose) for activities and can improve them to provide competitive advantage. In other words, analysis of internal activities reveals where the company's competitive advantages or disadvantages are. The company, which competes with the purpose of divergence, seeks to carry out its operations rather than competitors. If it competes by price advantage, it tries to maintain internal operations less expensive than competitors. The company that has the ability to produce goods at a lower cost than the market price or deliver superior products will get benefits.

\section{Importance}

The value chain frame has led to the forefront of management thinking as a powerful tool for quick strategic planning. The simplest concept of value currents, a cross-functional process developed in the next decade, achieved some success in the early 1990s.

The value of the value chain is expanded beyond individual entities. It can apply to all supply chains and distribution networks. Providing a mix of products and services to ultimate customers, various economic factors are assembled, each with its own value chain management. The industry's wide synchronized interactions of local valuable chains create an extensive value chain, sometimes in the range of the world. Porter tells this large interconnected system value value chains "value system". The supply chain of a company's supplier (and their suppliers backwards), the company, the company distribution distribution channels and the company's buyers (and extended to their product purchasers) and a value system.

A new approach taken by a number of management strategists, including the value produced along the chain. For example, the manufacturer may require its components to reduce the cost of transportation to its assembly plant near the assembly. By exploiting upstream and down stream information flowing along the value array, companies may try to skip the middlemen who create new business models, or improve their value system in other ways.

Value chain analysis has also been used in large petrochemical plant management companies to show how to help lean policies for management, work planning, work scheduling, and finally work execution (when considered as elements of chins). The Management Value Chain System is particularly successful when used as a tool to help change the appearance of user-visible than other management processes.

With a lack of publicly known data from the direct corporation, for example, a valuable chain industry can provide a meaningful alternative to analyzing private or public companies in order to have a good bottom industry and good feel. Its value is by building useful correlations with its bottom companies.

\section{Benefits of Value Chain Management}

\section{Reduce delivery times}

Any distribution channel member can benefit from reduced delivery times. A manufacturer can strengthen relationships by hiring orders or retailers more quickly. Resellers make a profit because they 
coordinate more efficient buying and selling activities. Moreover, end-users will benefit from endusers and more sustainable on-delivery when trading channel partners efficiently move objects.

\section{Optimized Inventory}

There is a close connection with fast delivery times. Retailers can work together with suppliers to reduce delivery times and to coordinate manufacturer's outbound approaches with the internal logistics of the retailer. Many retail values use "in-time" list routines as part of the chain management. With JIT, retailers are often more likely to order small items. The high list is expensive to maintain and increase the likelihood of waste. However, the retailer needs to rely on his relationship with sellers to avoid shortages.

Improve customer relationships

By conducting the initial value chain factor, bound logistics, operations and outbound logistics, resellers can improve reaction time and reduce costs for customers. The value chain's marketing and sales and service items are important to improve customer relationships. Many resellers use obedience or complementary programs to persuade customers to produce customer loyalty and purchase of seasonal products. It is also important to help customer follow on customer experiences to ensure continued service satisfaction.

\section{Increase revenue and profit}

In the end, the bottom line benefits of value chain management are enhanced with revenue and profit. With efficient logistics and distribution, you can get products when customers need it. Your marketing and sales efforts will help customers attract and buy goods and promote higher prices. Reduced logistics and distribution costs and proper price points and income can contribute to the best profit for your small business.

\section{Reference}

1. Grant, R.M. (2010). Contemporary Strategy Analysis. 7th ed. John Wiley \& Sons

2. Benefits of Value Chain Management by Neil Kokemuller

3. https://en.wikipedia.org/wiki/Value_chain

4. https://www.toolshero.com/management/valuechain-analysis-porter/

5. https://www.strategicmanagementinsight.com/tool s/value-chain-analysis.html

6. http://www.netmba.com/strategy/value-chain/

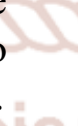

